Canadian Journal of Family and Youth, 1(2), 2008, 75-111

ISSN 1718-9748@Univeristy of Alberta

http://ejournals.library.ualberta.ca/index/php/cjfy

An Exploration of the Experiences of Inter-racial Couples

Temitope Oriola

\begin{abstract}
This study utilizes in-depth interviews of five interracial heterosexual couples to explore how couples live, and re/de/construct their everyday lives within a multiethnic society. I examine how couples experience public spaces, negotiate their identities, raise biracial children and confront cultural differences. The study also investigates the process of acceptance of partners by couples' respective families and the media representation of interracial relationships. This paper demonstrates that minority families are more likely to raise strong objections or resistance to their children marrying Whites. Another major finding of this study is that subjects experience gradual shifts in their identities and changes in their worldviews as a result of their relationships with their spouses regardless of whether they adopt a 'colourblind' or 'colour-conscious' approach. Subjects' narratives are also laced with intermingling discourse of race and culture.
\end{abstract}

\title{
Introduction
}

More than most concepts, 'race' and its concomitant outcomes like racism, racialization and racial profiling have been subjects of intense debate by the academia and laity ${ }^{1}$. Amid widespread issues of marginalization and inequality, it is easy to dismiss the ties that bind some members of the various groups - dominant or dominated together ${ }^{2}$. One of these is interracial intimacy like common-law heterosexual unions and

\footnotetext{
Temitope Oriola is a doctoral student at the Department of Sociology, University of Alberta in Edmonton, Canada. His areas of research include (counter) terrorism, oil and social banditry and race/ethnicity/policing. His publications have appeared in journals such as the African Journal of Criminology and Criminal Justice and Critical Studies on Terrorism (forthcoming). Oriola can be contacted at oriola@ualberta.ca

${ }^{1}$ It is neither my intention nor the purpose of this study to engage with the concept of 'race' even cursorily. Suffice to state that I take race as a social construction, yet one with enormous social consequences (see generally: Goldberg, 2002; Goseett, 1997; Omi and Winant, 1986; Gilroy, 1987; Mosse, 1978).

${ }^{2}$ This is by no means downplaying the salience of marginalization, discrimination and other existential issues.
} 


\section{Temitope Oriola}

marriages. Why do some individuals in spite of the 'one drop of blood' rule, widespread stereotypes, social (mis)construction of the Other, potential loss of privilege and historically entrenched and societally enforced boundaries cross the colour line when it comes to love and/or marriage? How do interracial couples negotiate their way in public spaces and raise biracial kids? What influence does their relationship have on their worldview and identities? How does society encompassing significant others like family, friends, neighbours, and the sea of unknown faces they encounter daily relate with them? How do interracial couples assess the representation of interracial unions on Canadian television? These are the questions this study attempted to explore through in-depth interviews conducted with five interracial couples in Canada between February and March, 2008.

\section{Integration and Social Construction of Interracial Unions}

Most studies done on interracial unions are American or British in origin, even though Canada, compared to the United States, has a higher proportion of interracial couples (Milan and Hamm, 2004). There are, however, some Canadian studies on the unease over mixed race offspring from heterosexual relations between First Nations' women and White men in British Colombia by Mawani (2002) and the experiences of White women involved with Black men by Deliovsky (2002). From issues such as the media representations of interracial relationships as aberration, events and/or spectacles (Perry and Sutton, 2006) to the contestedness of the identity of children of interracial couples (Barn and Harman, 2006), to why young, upwardly mobile and career-driven Black men ostensibly prefer White women regardless of class (Craig-Henderson, 2006) 


\section{Experiences of Inter-racial Couples}

to short (melo-dramatic) autobiographical accounts of interracially-involved young people (Alderman, 2007) to the making of 'multiracials' and the problematic of the intersticial space of mixedness (DaCosta, 2007), to the ironic and paradoxical contradiction of 'talking Black, sleeping White' among some activists in post-bellum United States (Romano, 2003); interracial relationships have come to stay as evidenced in the 'proliferation' of those called a myriad of names like 'coloured', 'mulattoes,' 'halfcaste' and 'mixed race' (Barn and Harman, 2006: 1314) but are still largely seen as problematic. There is an urgent need to fill the intriguing lacuna in the Canadian literature on the experiences of interracial couples.

Milan and Hamm (2004: 2-5) provide an analysis of groups most likely to be interracially married or in common law unions in Canada. The Japanese rank first, Latin Americans are second, while Blacks are third. South Asians and the Chinese are least likely to marry outside their group in Canada. The same holds true in the U.S (Fu, 2007: 230). The significance of increasing numbers of interracial couples cannot be overemphasized. Canada's multiculturalism policy is aimed at inclusion and integration, though not without its critics (see Seljak, 2005; Bisoondath, 2002; Bannerji, 2000). It has been argued that when society becomes positively welcoming to interracial coupling, integration is not far fetched (Kennedy, 2003; Childs, 2005). Therefore, through the stories and experiences of interracial couples, this study attempts to unpack the ways that integration is understood, (de)constructed, challenged, problematized, narrated and conceptualized in couples' daily experience and popular media.

Canada, as stated earlier, has a higher proportion of interracial unions (marriages and common-law) than the United States (Milan and Hamm, 2004). Utilizing the 1991 


\section{Temitope Oriola}

and 2001 Canadian census figures, Milan and Hamm (2004) estimate that $3.2 \%$ of couples in Canada are racially mixed couples (with one visible minority partner and a Caucasian spouse). This represents an increase of 35\% over 1991 figures. Persons in interracial unions were found to have very high levels of education, live in metropolitan areas, to be generally quite young and are largely foreign-born. Also, factors like greater societal acceptance of 'non-traditional behaviours' account for the increasing rate of interracial unions. The 2006 Canadian census shows that $3.9 \%$ of unions in Canada were mixed, while $3.3 \%$ of all unions (marriages and common law) involved one visible minority and a non-visible minority (Statistics Canada, 2008: 16). As of 2000, $2 \%$ of all couples who were married or in common-law in the US were mixed unions (Milan and Hamm (2004: 5).

\section{Methodology}

This study is situated within a qualitative framework because, as Ighodaro (2006) argues, it is the most apt methodology for unearthing situations where certain people are 'living the experience' that is not necessarily shared by others in the society. Despite their increasing numbers, interracial couples are the exception to the norm and are few and far between in Canada. This study primarily focuses on interracial heterosexual couples. While I do not privilege heterosexualism, I focus on interracial heterosexual couples because heterosexuality is more ubiquitous. I rely on snowball sampling to recruit subjects and thus employ and deploy personal contacts to select potential subjects.

In-depth interviews are utilized to get into the life world of five interracial couples with a view to sharing their experiences (see Briggs, 2007; Repley, 2006; Miller and 


\section{Experiences of Inter-racial Couples}

Crabtree, 2004). Three of the interviews were done face-to-face with couples in Edmonton, Alberta. The other two interviews were conducted over the phone. One of the over-the-phone interviews was with a couple in Winnipeg, Manitoba and the other phone interview was with a couple in Edmonton. The data obtained were transcribed, cleaned, anonymized — all names used are pseudonyms to ensure anonymity of subjects — and coded into 19 thematic categories. These include themes like "Universalistic vs. particularistic identity discourse," "Colour-blind vs. colour-conscious discourse," "Cosmopolitan worldview vs. Non-cosmopolitan worldview," "Commonality," "Narrative (non)cohesion," "Dating/attraction," "Family response," "Exoticism" among others. One of the telephone interviews involved a couple in Winnipeg, while the other couple (Mark and Melina) interviewed on the phone was based in Edmonton. Apart from Mark and Melina (owing to their different schedules and at their behest), all interviews involved both partners at the same time. A major limitation of this study is the small number of subjects interviewed.

'Interracial union' is operationalized as a heterosexual relationship — marriage or common law — involving one self-declared visible minority spouse and a White partner. This assumption in and of itself is not unproblematic, but depicts a theoretical choice and thus shapes this study. I choose to select couples with one White partner and not visible minority couples because of the power and privilege questions associated with whiteness (Brodkin, 2004; Weis, Proweller and Centrie, 2004; Oliver and Shapira, 1997; Frakenberg, 1993). Experiences and stories of the subjects, it is hoped, would help to shed light on the supposed 'two worlds' of a White/Non-White couple. 


\section{Temitope Oriola}

\section{Meet the couples}

The five couples interviewed for the study come from an array of backgrounds. All information presented below was provided by the subjects at the time of the interview:

1. Mary and Joseph: Mary is a 32 year old White Canadian. She has been married to Joseph for seven years. Joseph is a 33 year old Black Canadian. He was born in Ethiopia and is currently a student of Nursing. Joseph and Mary are born-again Pentecostal Christians and have two boys aged six and four respectively. Mary is a sit-at-home mother and helps in home-schooling the two children. The couple was interviewed over the phone.

2. Tony and Maya: Tony is a 46 year old White Canadian, Ukrainian in origin. He works as a Senior Under-writer and is a Catholic. He is college educated. Maya (age unspecified) was born and raised in British Columbia of Chinese biological parentage. She is college educated and works as a Senior Probation Officer. Maya has no religion. She has been married to Tony for two years. They have no children and do not plan to have any.

3. John and Rachel: John is a White Canadian (of German, Mennonite, French background). He is an engineer and has no religion. Rachel is from Punjab, India and moved to Canada with her parents at the age of eight. Like her parents, her religion is Sikhism. She is a graduate student and has been in a relationship with John for 23 years and married for 15 of those years. They are both 43 years old and have a three-year old daughter, whom the couple maintains will remain an only child. 


\section{Experiences of Inter-racial Couples}

4. Bob and Charity: Bob is a 26 year old White Canadian and a graduate student. He met Charity six years ago and they have been married for one year. Charity is a 25 year old Filipina-Canadian. She was born in the Philippines and arrived in Canada in 2000 with her mother and brother. She is also college educated. They have no children at the moment.

5. Mark and Melina: The interview with this couple was conducted over the phone even though the couple lives in Edmonton. Because of the couple's schedule and at their behest, I conducted the interview with the couple separately beginning with Mark. This is the only couple not interviewed together. Mark is a 60 year old engineer. He is a White Canadian born on a Saskatchewan farm. Melina is a 47 year old Black African woman born and raised in Mali. She is a certified secretary. Mark and Melina have been married for three years and are expecting a baby.

In summary, the couples are Black Ethiopian male with a White female (Mary and Joseph), a White male and an Indian female (John and Rachel), a White male and a Black Malian female (Mark and Melina), a White male and a Chinese female (Tony and Maya) and finally a White male and a Filipino female (Bob and Charity). Among the visible minority spouses, all but one subject, Maya, a Chinese-Canadian, are foreign born.

\section{A Black male interviewer and White subjects}

The literature on the practice and theory of minority researchers matched with White subjects is very scant (Sin, 2007: 479). Research on field work is essentially 


\section{Temitope Oriola}

focused on White researchers working with minority subjects, but rarely the other way round (Gunaratnam, 2003). However, this study was designed to examine interracial couples and by operational definition minority spouses with White partners. As a Black male interviewing interracial couples, I hoped that my identity would not inhibit White subjects from freely expressing their opinions. My first subjects, Joseph and Mary whom I interviewed on the phone were already known to me for at least one year before the interview. Mary, who is White, was very candid and reiterated how she had become more sensitive to issues of racism since she got married to Joseph. Perhaps the rapport I had established with her and her family long before conceiving this study was a factor in making her to bare her mind without any restraints.

My second interview provides a possible influence of my identity on the responses I got while asking questions that may be considered sensitive (see Davis, 1997) during the interview (Briggs, 2007; Rapley, 2006). Tony is White and is married to Maya who is a Chinese-Canadian. Tony adopts a near-absolute colour-blind discourse. I often directed the questions at him before allowing Maya to respond having observed that Maya was likely to respond to questions with greater detail and anecdotes. However, after giving a terse answer to a question, Maya would respond to the same question with greater clarity and elaboration, thereafter, Tony would go back to answer the same question with greater detail. This could be seen as a case of testing the waters. For instance, when asked if they think having more people marry interracially can enhance integration among Canadians, the following response follows:

Tony: Sure. But I don't really have an explanation to follow that up. Maya: I think so. Vancouver, I find, where I was born and raised is more open. I find Alberta is more redneck, because I'm not from here. I think it does improve the visibility of multiculturalism. 


\section{Experiences of Inter-racial Couples}

Tony: I haven't really come across any problem.

Maya: Yeah, I know. In Alberta, interracial couples seem to be more forgotten. Albertans from my experience are more reckneck and more narrow-minded. I don't want to stereotype Albertans, but Vancouver, BC is more open.

Tony: Maybe there's more Caucasians here and more minorities in Vancouver.

As Childs (2005: 110) finds in her study, asking White subjects to talk about their families' views about interracial marriage is often very controversial. Tony states that his family had no objections to his marriage but emphasizes that times are changing and different from when his parents were growing up. His tone was rather measured and tortured on the topic and he appeared less comfortable than his wife on the topic. Available literature shows that whiteness is in no way invisible (Sin, 2007; Frankenberg, 2003) and in certain contexts, can become the other (Sin, 2007; Fechter, 2005).

In addition, the impact of gender on social scientific research is very complex and has been gathering scholarly focus (Sampson and Thomas, 2003; Warren, 1988). For instance, female researchers, Sampson and Thomas (2003: 177), demonstrate how a number of males in their seafarer interviews made 'unsolicited emotional disclosures' to them apparently because of gender stereotypes of women as 'good listeners'. Rapoport and Rapoport (1976: 32) show in their study of dual-career families that some women preferred to be interviewed by men, while some men were 'particularly responsive' to women interviewers. Padfield and Procter, (1996) find that women interviewees revealed a more intimate aspect of their lives - experience of abortion - to the female researcher while only discussing abortion in generic terms with the male researcher. Nonetheless, the impact of gender on the interviewing process remains tenuous to track. 


\section{Temitope Oriola}

It is possible, therefore, that my gender as well as race may have had an effect on the responses of subjects during the interviews. As previously noted, apart from Mark and Melina (a White male and a Black Malian female), all couples were interviewed together. Melina certainly opened up more to me than Mark, especially on how they met and the warm reception she received from his family. I had known Joseph and Mary (Black Ethiopian male and White female) for a fairly long period of time before the interview was conducted. Hence, trust had long been established. Both of them, particularly Mary, exhibited no inhibitions in discussing sensitive issues like racism as the analysis below shows.

During the interview with Tony and Maya (a White male and a Chinese female), I noticed that though I met both of them in person on the interview date, as stated earlier, Maya provided much longer answers laced with anecdotes and vivid recollections of events than Tony did. ${ }^{3}$ In the case of John and Rachel (a White male and an Indian female), both of them answered questions with similar eagerness. During the interview with Bob and Charity (White male and a Filipina), although Bob was enthusiastic and provided detailed responses, Charity was even more so. Therefore, in most cases, the female subjects in this study regardless of their race were generally more outspoken, answered questions with lesser inhibitions and generally appeared to enjoy the experience more than their spouses. Maya and Charity, for instance, stated that they wished the interviews were longer. Speculating on what this might mean, especially in light of the small sample, is beyond the purview of this paper.

\footnotetext{
${ }^{3} \mathrm{I}$ had been in contact with Maya by phone and e-mail.
} 
Experiences of Inter-racial Couples

\section{Data Analysis — Interviews}

In this section, findings from the interviews with all five couples are presented under thematic issues. These include reaction of subjects' families to their choice of spouses, experiences in public spaces, shifts in identities and changes in the worldview of subjects, concerns about the identities of their biracial children, experiences in public spaces and media representation. The results show how divergent subjects' experiences were when they introduced their partners to their families, how they began to learn, adopt and adapt to otherwise 'alien' cultures, and what impact these have had on their identities. The results indicate that except in one case, minority families are generally reluctant to accept their children's White partners. Subjects also opine that the medium of television and movies seldom cast couples that look like them preferring to depict more 'conventional' couples.

\section{'You can date a White woman, but you marry a Black woman'}

Family and marriage is the most intimate sphere of society (Romano, 2003). Thus, the significance of increasing numbers of interracial couples cannot be overemphasized. As stated earlier, when a society becomes positively welcoming to interracial coupling, integration is not far fetched (Kennedy, 2003; Childs, 2005). As Myrdal (1962) found out, intermarriage and sexual relationships involving Whites and Blacks in particular, was strongly opposed and laws were enacted to punish those who dissented. Thus, I asked each couple in this study about how their families reacted to their choice of spouse. Joseph (33 year old Black male, Ethiopian-Canadian and nursing student) says his parents vehemently opposed his relationship with Mary (32 year old 


\section{Temitope Oriola}

White female, home mother with two years of college). According to Joseph; ' $(m) y$ friends said you can date a white woman, but you marry a black woman...I thought I would only use a white woman and marry a black woman.' Joseph explains that in Ethiopia, Whites are favourably viewed because of their involvement in missionary and humanitarian activities but that 'marriage is different. You don't want to marry a white person; you are expected to marry an Ethiopian.' Therefore, when his family realized he was bent on marrying a White woman he says:

They thought I was crazy...My parents and brother did not agree; only my little sister supported the idea. Nobody in my family showed up for the wedding. They disowned me and nobody from my family spoke with me for three years. So my family was the major problem not hers.

Joseph had expected to face opposition from his White partner's family and not his.

Negative reaction and opposition to interracial marriage and outright disowning of children who marry Whites is common among Black families (Craig-Henderson, 2006: 112; Childs, 2005: 123-125).

One can safely hypothesize that interracial unions involving Whites and Asians are less likely to be racially charged than those in which Black partners are involved with Whites. Asians have a long immigration history in Canada, enjoy greater levels of assimilation in the West generally and as Dorow (2006: 361) demonstrates, are seen as the 'model minority,' favoured over and above Blacks even in the 'racialized choices' of transnational adoption. However, Mary's family was more supportive of their daughter. Mary explains that her mother told her that she trusted her judgment. Nonetheless, one of Mary's friend suggested what Childs (2005: 152) discovers that people think is the reason why Black men marry White women - to use them as a means to an end. The same thing is often said about White women married to rich Black men. One of Mary's friends 


\section{Experiences of Inter-racial Couples}

was concerned that Joseph was in a hurry to marry her because he wanted to become a Canadian citizen. She explained to her friend that he was already a Canadian citizen.

Tony (46 year old White male, college-educated) met his wife Maya (age unspecified, Chinese-Canadian, college-educated) on a blind date arranged by a mutual friend. They dated for two years before getting married. Tony says his family had no problems accepting Maya, while Maya's brother did not accept her choice of partner, but she declined to go into the details. Also, her parents had always been clear about what they wanted for her:

(W)hen I was growing up, my parents said to me you should marry an Asian person because culture and values are very important to us and we have to maintain the tradition because Caucasian people have different values and expectations. Our culture teaches us to go to school... we respect our elders, we live up to family obligations... You know, you are an Asian person, you do better.

Apart from Tony's family, who had no objections (a point I return to later on), a recurrent issue in how families reacted to the choice of their children's partners is the difference in culture and racism in the society. Subjects' experiences glaringly show a complex interplay of race and culture. This perhaps speaks to the substitution of culture for race, hence, shrouding racial thoughts, imaginations and biases in cultural terms. This has generated volumes of work in cultural studies (see generally, Gilroy, 1990; 1991; 1993; 2000; Hall, 1997; Hall and du Gay, 1996).

Families wanted their children to marry persons from similar cultural backgrounds. Charity's (25 year old Filipina-Canadian) mother too did not want her daughter to date or marry Bob (26 year old White Irish-Canadian, Graduate student) because she wanted to uphold the Filipino culture and was not sure of Bob's intentions. Bob's American mother also had her reservations. She was concerned 


\section{Temitope Oriola}

about how they would be treated in the society. Bob's mother's 'concern' is similar to what Childs (2005: 123) finds with White college students, whose parents feared that their kids would make their lives unnecessarily difficult (in terms of housing, employment, socialization of their children, etc) and thus tacitly implied concern over loss of White privilege or 'unearned advantages' by their kids. At the heart of this concern and preference is that skin-colour still does matter in the society. On the other hand, Mark (46 year old White Canadian, Civil Engineer) and Melina's (45 year old Malian-Canadian) families approved of their relationship from the onset. In all, apart from Melina's family, all minority partners' families had reactions ranging from negative to mixed feelings about their children's spouses, while these same partners were generally well received by the White families of their spouses.

\section{The Gaze and the Public Domain}

Like other couples, interracial couples go to public spaces like malls, stores and restaurants together. Au courant that public spaces are domains of contestation, particularly in the face of 'unmaskable diversities' such as skin colour (Lofland, 1973: 86), I wanted to know how it feels to show up in public with a partner of another race and the reaction of those Sacks (1972: 444-5) calls the 'public-spirited citizen'. In assessing other people in public spaces in terms of appearance or mannerisms, there is the possibility of a 'judgmental gaze' (Burgin, 2002: 235) or in the worst case scenario, a 'hate stare' (Griffin, 2006: 51-52) on those deemed to be out of 'place.' Littering everyday hustle and bustle, are networks of observers and people having no other stake in public spaces than the fact of being citizens (Sacks, 1972). This is done through eye 


\section{Experiences of Inter-racial Couples}

contacts or the gaze. The eye 'serves not only for me to know the other but also enables him (sic) to know me... it conveys to the other the real personality, the real attitude, and the real impulse' (Simmel, 1969: 358-9)

While Joseph does not notice or read meanings to how he and his wife are stared at in public, Mary clearly observes how they are stared at in public and explains that '(p)eople treat different races differently. You can tell by their looks whether they think it [that is, interracial marriage] is right or not.' She cites an incident at a gathering where an aunt from her Amish family stared at Joseph for so long that she called Mary aside to tell her it was 'okay' to marry him. Mary said she knew her aunt did not think it was okay judging by the way she stared at Joseph. What Mary points to here is not only a ‘judgmental gaze’ (Burgin, 2002: 235), but also a discourse of political correctness, in which people hardly say what is on their mind; a discerning observer however can easily read between the lines.

On the other hand, Tony has not noticed anything untoward in public spaces and argues that he has not observed being stared at or heard anyone making any negative comments. His partner, Maya, who is Chinese, however, observes that when she went to Shanghai with Tony, people stared at them a lot because they don't usually see a White/Chinese couple often. This is not necessarily a negative or judgmental gaze. Maya also observes the difference in the way they are treated when she goes to Chinese restaurants in Edmonton with Tony. She notes subtle things like offering them the cheapest tea rather than asking them what they wanted as they would if she was with her Chinese friends:

(I)t's kind of a reverse discrimination. If I go in with Asian friends, they'll ask us in Chinese what type of tea we want, but if I go with Tony, 


\section{Temitope Oriola}

they don't bother to ask they just give us the generic one probably the cheapest one. I noticed that.

It is useful to note that in both cases cited above the 'dominant' partner in each context or social milieu — Mary in Winnipeg and Maya in China — noticed the gaze.

\section{Shifting Identities, Changing Worldviews}

This section demonstrates how subjects' identities go through a process of construction and reconstruction based on their relationship with spouses from different ethno-cultural backgrounds and in relation to the space engendered by a multiethnic society. To this end, I examine subjects' views about themselves, their identities and those of their spouses in relation to the world around them. Of particular interest is whether or not subjects have become more or less 'colour-blind' or 'colour-conscious' and what impact this has on their worldviews. Being colour-blind here means thinking and acting in a way that effectively makes an individual not to see race, while colour consciousness implies actively seeing or reading racial connotations or denotations in everyday encounters. In other words, this section examines the identities of subjects and addresses the questions: Do interracial couples see race? How does this influence the way they view the world around them?

Identities are non-static, fluid and in a constant state of formation (Donaldson and Jedwab, 2003; Bhabha, 1994). For Donaldson and Jedwab (2003: 2), identities are constantly subjected to negotiation and re-negotiation, 'a process generally influenced by a variety of factors including the respective importance of markers of individual identity and the conditions under which they are manifested.' Of very fundamental importance to questions of identity are space, social interaction and dislocation (Papastergiadis, 2000). 


\section{Experiences of Inter-racial Couples}

In multiethnic societies like Canada, questions of identity are based on the interplay of ascribed and socially-defined factors which shape people's sense of self, treatment and experience (Puplampu and Tettey, 2005). For these authors, skin colour is the most consistently used criterion. Identity, it is believed, is increasingly racialized ( $\mathrm{Li}, 2003: 54)$ and ethnicized (Puplampu and Tettey, 2005). Consequently, the experience of racialization or the attribution of personality traits and behaviours to people based on biological characteristics such as skin colour (Tanovich, 2006), is intertwined with identity. This experience not only shapes identity construction, but also has a direct relationship with worldview and standpoint on any issues (Frankenberg, 1993). Apart from race, age, gender, disability, sexual orientation, socio-economic factors, ethnicity, culture and religion (Donaldson and Jedwab, 2003) are identity markers.

The level of race consciousness and identities of partners in this study provides a fascinating example of what G.H. Mead (see Charon, 1992) calls 'role-taking' except that here, it is by adults and not young children who are just learning a sense of self. Joseph has become more colour-blind (thinking and acting in a way that actively makes an individual not to see 'race') and less conscious of being a Black male emphasizing that when he looks at Mary, 'I see a woman I'm married to rather than a white woman.' He argues that being married to Mary has helped him to rely on his faith and that has also improved his worldview. Mary on the other hand, has become more conscious about issues around racial discrimination. She explains that:

I noticed the treatment is different when I go out with Joseph from when I go out with my friends who are white to restaurants for example...very racist... That is the irony, he is more colour blind now, I am less colourblind. I was colour-blind before. I knew there was racism in the past but didn't know it still existed until I met Joseph. I was overly naïve. 


\section{Temitope Oriola}

As Frankenberg (1993) finds in her study, White women become more aware of racism when in interracial relationships, hence Mary is no exception. It is almost like entering into a different world entirely; or what Frankenberg (1993) calls a 'social geography' of discrimination. The experience of the Black identity by marital association becomes intertwined with this subject's identity. Therefore, Mary has become more conscious about social injustices and discrimination in the system more than ever before because of her relationship with Joseph.

Explanations given by Tony provide a sharp contrast to his wife's and to Mary's. Tony opines that he has not come across any problem, but Maya argues that the people in Vancouver, British Colombia are more open to interracial couples than the people in Alberta. She says she finds Alberta to be more 'redneckish' and more 'narrow-minded,' but British Colombia where she was born and raised is more open and accepting. At this point, Tony interjects stating that it is perhaps because there are more racial minorities in Vancouver, British Colombia. To what extent Tony's standpoint approximates what Razack (1999) calls 'the will not to know' is unclear, but he is not alone in adopting a colour-blind, discourse. Mark and Melina, Joseph and John also share Tony’s standpoint. For instance, Mark told me very succinctly that '(w)e will skew your research.' He believes his background and that of his wife do not fit into what I might expect. ${ }^{4}$

Culture and race intermingle in subjects' narratives. Rather than explicitly use the word race, subjects speak of culture. For instance, Rachel (46 year old Indian-Canadian) explains that 'I think my Indianness has become more pronounced because we're part of a couple now. So before, no one really noticed that, but with John and when they see us together, all of a sudden, it's a mixed marriage.' Rachel's husband is White and she gets

\footnotetext{
${ }^{4}$ This is discussed under methodological reflection.
} 


\section{Experiences of Inter-racial Couples}

the feeling that her marriage makes her more visible and conscious of her background.

She states further that

.... a part of me didn't want to get lost in it [interracial marriage]. I didn't want to marry out of my culture and then negate it all together. I don't know if it was because of our marriage or not, but I noticed it's only being a few years that I started using the term 'Indian' to describe myself, before it was East Indian or Indo-Canadian you know some sort of hyphenated something, but now I've come into my own identity and I feel very comfortable being who I am. I don't know if it's because of my marriage or it's just me growing up.

Rachel's identity has thus gone through reconstruction and renegotiation as she grows up with the only man she has loved and been with since she was 20 . John too says being married to Rachel has made him to pay more attention to his roots. They both agree that their worldviews have become significantly broadened and they have become a lot more tolerant and 'worldly.' For John, there are now more concerns beyond Canada and North America, since he visited India with his wife. He is better able to understand that countries like India are a lot different than he thought. Another subject, Bob says his marriage has put him into relations he would otherwise not have had, such as speaking at a very personal level with Filipino people. He believes that his relationship with Charity, who is Filipina, has broadened his worldview. However, he believes his roots are rather 'uninspiring,' but he has become more aware of his wife's background.

Mark argues that he is a born-again Christian, who grew up with many ethnic groups including a First Nation nanny, and has worked in Mali for many years; hence his worldview has not changed by virtue of his marriage. He argues that his wife, Melina is actually more westernized than he is having grown up and worked with missionaries from Canada and the United States. Melina also explains that having traveled to various parts of the world; she already had a broad worldview and felt at home everywhere. 


\section{Temitope Oriola}

However, other couples interviewed have had significant changes in their worldviews and have become more conscious of their ethnic identities and are better able to feel comfortable with social difference as a result of their relationship. Vertovec and Cohen (2004: 4) refer to this ability to feel at home with divergent cultures and standpoints, broadening one's worldview, transcending any particular nation-state essentialism, being oriented towards both the universal and the particular and representing a plethora of allegiance, identity and interests as 'cosmopolitanism,' an idea dating back to Immanuel Kant (see Kant, 2006). Therefore, subjects in this study are becoming increasingly cosmopolitan in their attitudes and worldviews. Whether they adopt a colour-blind or colour-conscious approach, they feel connected to multifarious identities, cultures and social networks and have increasingly broadened worldviews.

\section{Culture and worldviews: Becoming 'worthy'}

Couples also found how the worldviews of their families differ markedly in very important respects. Rachel said she hid John from her family for eight years because she could not introduce him as her boyfriend. She stated that she knew he would have to be her fiancé with the date of marriage set before she could introduce him to her family. John stated that at a point in their relationship, he was advised to withdraw from school because of poor grades and thus dropped out. He said 'I knew I had to get back to school to be worthy of her family. I figured it out that I have to have a presence of some sort.' This speaks not only to the high level of education among a lot of diaspora minority communities, ( $\mathrm{Li}, 2003)$ but also the high expectations and standards that they hold their children to. Also, the couple could not believe Rachel's parents' objections to their traveling to Calgary together for a weekend even with their marriage date a few days 


\section{Experiences of Inter-racial Couples}

away. Older minority community members tend to hold on to their norms and values which emphasize little or no bodily intimacy between partners before marriage and expect their children to conform.

It is fascinating to note that the cultural differences on co-habitation were very striking between Bob and Charity's families. Specifically, Bob's cultural background came into conflict with Charity's before their marriage. Bob's parents felt cohabitation was 'the thing to do' with one's potential life partner before marriage, but Charity's mother was furious. Charity said her mother told her she was acting like a Canadian and that were Bob Filipino, he would not ask her to move in with him before marriage. She threatened to disown her, but was very excited when she saw Charity's engagement ring afterwards.

In the course of the interviews, issues of religious and cultural differences also came up with some of the couples. Bob for instance, noted that he had to pay several visits to Charity's Catholic church to demonstrate to her mother that despite his nonreligious lifestyle, he was not anti-religion. The idea of co-habitation also shows cultural differences between the families of Bob and Charity. However, for couples like Joseph and Mary and Mark and Melina, their religious faiths were the same and equally strong and enhanced acceptance by their families. According to Mark, Melina's strong faith was the major reason he married her. Melina also saw Mark as a strong candidate for marriage because of his faith and missionary work and that also endeared him to her family. The Christian faith is also the commonality that Mary and Joseph have and that in fact brought them together. For instance, asked what advice they have for other couples, Joseph and Mary said 


\section{Temitope Oriola}

Joseph: It's not easy. Being believers is what makes us to survive. It is very difficult. Race is an issue but because we are believers, it makes it easier.

Mary: Have a solid interest on something you agree on, something outside your culture and race. We know it is God.

\section{'I want their Identity to be human': Raising biracial children}

Raising biracial children has been highly problematized in public discourse and academic literature (DaCosta, 2007: 112; Barn and Harman, 2006). I was curious to know what couples think about the identity of their children. Joseph and Mary offer a glimpse into the challenges of raising children of biracial heritage. They have two boys who are under 10 years and explain what they envision for their children:

Mary: I want their identity to be human.

Joseph: I'm happy to have them hanging around Black people in our new church. It's the reason I'm happy we left previous churches which were all White. The new church is diverse. As long as they are colour-blind, I'm fine with it. I'd love them to like the language (Ethiopian) and adopt a Godly Canadian culture and take the positive aspect of every culture we live in.

Mary adopts a universalistic approach, hence the word 'human' while Joseph is more particularistic about their children's identity. Joseph's expression of happiness about the diversity of their new church shows that he wants his children to closely identify with Black people. The church in question has more Nigerians than Ethiopians; groups that are as different as British and Ukrainians in Europe. However, he is pleased to have them socialize with other Black people. The blend of particularistic and universalistic ideals in this couple's narrative is not necessarily contradictory. Joseph wants to see his children comfortable in whom they are as Blacks, and able to relate well with other people without inhibitions. 
Experiences of Inter-racial Couples

Even though Charity and Bob do not have children yet, Charity says she is 'conscious' of and 'anxious' to know what their children will look like, having noticed that unions like theirs (White-Filipino couple) produce children who largely look Filipino. Bob says he expects their children to look Filipino and that he does not mind. However, he says he 'hope(s) that by the time they're in the world that things are even better as far as racism and such because they might face that.' Pressed further about their children's identity, Charity says she wonders if they will be 'Fil-Can' or 'FilipinoCanadian.' They want racially diverse public schools for their children, but worry about schools in general. Bob remembers he had a Filipino student as a classmate in grade four and they all stared at him endlessly wondering where he was from and why he looked different from them. In retrospect, he believes that must have been difficult for a young Filipino student in an all-white school to handle. Bob states further:

I'm worried that they might stay along racial lines especially through...school. Kids tend to form cliques. Personally, I don't want my kids to become ostracized in that way along racial lines and kids tend to do that. So, that's my worry, identifying as or being identified as Filipino and forced to only hang out with certain groups just because of their appearance. That will worry me.

Bob was visibly emotionally shaken as he made this statement. Therefore, his initial universalistic discourse about his children's possible Filipino appearance eclipses as soon as the grim possibility of their not being fully integrated with other children weighs on his mind.

Rachel (Indian female) and John (White male) have similar concerns about their only daughter. While John wants to learn Punjabi, which he has agreed to have his wife teach their daughter, Rachel is concerned about the time "when other children start 


\section{Temitope Oriola}

questioning her that her mother doesn't look like her.' Their daughter is White, blonde and blue eyed, though Rachel is Indian. Rachel wants her to learn both Canadian and Indian culture without one dominating the other. In fact, so particular was Rachel about her daughter learning Punjabi (and hence her identity) that she says 'if she doesn't, it'll be ridiculous.' Melina (Black female originally from Mali) and Mark (White male) also want their child to be exposed to their backgrounds. Melina wants her child to learn French, as a Malian, and not be a 'complete stranger in Mali'.

\section{Media (mis)representation: The 'perfect people'}

The media represent a very powerful tool for cultural production and representation (O’Brien and Szeman, 2004; Henry and Tator, 2002:4; Hall, Critcher, Jefferson, Clarke and Roberts 1978). The relationship between the media and public opinion can be arguably described as circular: the public partly shapes what the media report and the media shape public discourse. Available evidence shows that minorities in general are subjects of image distortion and misrepresentation in the media (Henry, Tator, Mattis and Rees, 2000: 295; Mosher, 1998: 129; Wortley, Hagan and Macmillan, 1997:637-76; Hall, Critcher, Jefferson, Clarke, and Roberts, 1978). Also, interracial relationships are depicted as either relatively unproblematic or exceptional (Perry and Sutton, 2006: 895). I asked all subjects what they think about interracial couples in the media. I begin with Tony and Maya:

Tony: Hmm. I don't think I see that many interracial couples.

Maya: I don't know maybe... (pauses) because the media tend to clarify a lot of things; everything has to be perfect. I was wondering maybe because they think generally people may not be accepting of it still I don't know. Like you don't see fat people in a show; and if they do, a fat person or Asian person is always stereotyped. The Asian person plays 


\section{Experiences of Inter-racial Couples}

the one that has the slanted eyes and speaks broken English and the geeky guy and does the kung fu rather than being a starring role. It's like in TV they visualize the perfect people and have the perfect White male and White female rather than the interracial couple or the slim person plus a middle-age weight person. I think that's probably why.

Responses given by Tony and Maya are congruent with Henry, et al's (2000:297314) argument that there is an invisibility of people of colour in the media, stereotypical portrayal and misrepresentation. Maya was born and raised in Canada, speaks good English and wonders why Asians on television are often given peripheral roles that require them to speak bad English. Bob wonders if it has to do with who makes the movies. He believes that a producer typically produces many shows and they tend to be 'older white men who come from a different generation as well. Perhaps we'll see changes if they're younger.' Younger people are more likely to engage in interracial relationships as earlier noted and as producers, may reflect that more.

Asked about the media, Mark argues that '(w)e don't identify with the media. We are not in that league... We don't take our cues from the media. We have an authoritative lifestyle. We are not taking in; we are shining out... It doesn't relate with us.' By 'authoritative lifestyle,' Mark means that he has a strong Christian faith and does not get influenced by the media. His wife, Melina, however, notes the absence of 'intercultural' couples on television. She says all such unions she knows have 'worked' and wonders why they are not shown on television..$^{5}$ Implicit in this is the idea that such relationships may be erroneously thought not to 'work.' Joseph and Mary do not watch television and could not answer any question on media representation of interracial couples, while Rachel and John believe interracial couples are not represented on television as well.

\footnotetext{
${ }^{5}$ As stated earlier, Mark and Melina were interviewed separately at their request. This was the only instance where their narratives differed on any issue.
} 


\section{Temitope Oriola}

\section{'I like to show off my wife' - The Exotic/Erotic Asian Woman}

Studies in the United States demonstrate that among all groups, Asian women are more likely to get married to White men, while African American women are the least likely to marry outside their group (Jacobs and Labov, 2002). More specifically, Korean, Japanese, Vietnamese, Filipino, Chinese and South East Asian women generally marry White men at a rate that 'far surpasses' the men from their group (Jacobs and Labov, 2002: 630). The inverse is the case for Asian men and African American men (CraigHenderson, 2006; Childs, 2005). The exception is Asian-Indian men who were found to be more likely to marry Whites than their female peers (Jacobs and Labov, 2002). Several reasons have been offered for why Asian women marry White men disproportionately in comparison to their male counterparts and females from other groups. Asian women are believed to be docile, exotic, highly domesticated and hence, controllable (Nemoto, 2006; Kim and Chung, 2005).

As noted earlier, four of the men in this study are White. One is married to a Black woman, while three are married to Asian women. Two of the White male subjects in this study demonstrate ample instances of eroticization and exoticization of their Asian spouses. For instance, subjects were asked: 'Would you say Canadians are accepting of interracial relationships?' The responses given by Charity and Bob are fascinating:

Charity: From my experience, yeah. I've seen a lot of couples of different ethnic origins, especially in Vancouver.

Bob: I think it makes a difference what the ethnicity and gender breakdown is. It's very common to see a white male with an Asian woman, less so to see an Asian man and a white woman and less so an Aboriginal.

Sensing an important opening, I asked Charity (Filipina): 'Is there any folk theory among Filipinos about why more Filipina marry white men?' Charity says 


\section{Experiences of Inter-racial Couples}

She believes 'it is just love and who you are attracted to. (Looking a bit flustered) I don't know.' As a graduate student, Bob works in the area of masculinities and certainly has an astute understanding of the trends and patterns in interracial marriages. Bob says:

I think it's an interesting issue particularly around the gender issue... I see a lot happening in the way it happens for us: White men, Asian women. Obviously an aspect of it has to come down to how a lot is going on in the culture as well; the eroticization of Asians. There is not as much eroticization of Asian men. Even those things become psychological, even though those are ugly issues to talk about...I mean the threat of another culture's men taking the dominant white woman for example black men and white women... It might raise more anxieties because it's taking "our women."

Bob is definitely aware of the interplay of race and gender and its impact on his choice of spouse and all of his friends whom he says are married to Asian women. He is cognizant of the sensual marketing and intricate web of inestimable sexual fantasies constructed around Asian women bodies (see Kim and Chung, 2005). On the other hand, Asian men are generally portrayed in popular culture and consciousness as asexual and not sexually desirable.

In a study of interracial relationships between Asian men and White women, Nemoto (2008) finds that Asian men are believed to be unromantic and their personal characteristics, such as sensitivity and unwillingness to share household chores are often linked to their origins by their White spouses. Bob's allusion to the societal perception of the 'threat' of marriages between Black men and White women is poignant and is widely supported in scholarly literature (Dacosta, 2007; Craig-Henderson, 2006; Childs, 2005; Romano, 2003; Jacobs and Labov, 2002; Frakenberg, 1993).

Racialized desires are a function of stereotypes as Nemoto (2006) points out. One subject, John, describes his titillating and exhilarating feelings about his wife years ago at 


\section{Temitope Oriola}

a restaurant. A friend of his overheard another couple describing his Indian wife, Rachel, as 'that exotic looking woman. He says 'I thought that's kinna cool...I love to show her off to my friends just because of who she is, the persona that she has, an exotic woman.' John's description of his wife as an 'exotic woman' in her presence drew laughter from all three of us. He explains how on occasions when he and his friends tried to 'check out' ladies (i.e comment on the attractiveness of women as they walked by), he was told 'that everyone I checked out on campus looked like Rachel. I like to be on the exotic side.' It is perhaps telling that when asked to suggest any question she would like included in this study, Rachel's recommendation was: 'Were you looking for someone of a particular ethnic origin when you found your spouse?' Social hierarchies of gender and race are thus fundamental to the enterprise of interracial marriage (Nemoto, 2006).

\section{(Re)Presenting Subjects'Voices and other Issues}

I have endeavoured to interpret and present responses of subjects as accurately as possible. Where there are no agreements among subjects - and that was often the case — alternative viewpoints of subjects are presented alongside what most of the subjects agree on (Markham, 2005). This is not only in keeping faith with polyvocality (Seale, Gobo, Gubrium and Silverman, 2004; Saukko, 2003), but also in recognition of the fact that there is no single reality anywhere and that researchers do violence to subjects by attempting to speak for them (Gilgun, 2005; Markham, 2005). My viewpoint thus comes close to an ethnomethodological perspective. Had I envisioned or stuck to the notion that interracial couples' lives would be a cacophony of confusion, I would be disappointed and frustrated by the findings of this study or might have interpreted the responses 


\section{Experiences of Inter-racial Couples}

differently. I avoided what for Palmer (2006) was a pitfall — the assumption that my subjects' lives were in need of a saviour — or presume that they might be frustrated with living together.

As Tjora (2006) admonishes, I have tried to minimize the influence of any subjective comprehension of the subject matter I may have had before conducting the study. In addition, being a $\mathrm{Ph} . \mathrm{D}$ student comes with its own unique little privileges and I do not and may not know the extent to which my level of education influenced the interview process. However, it was obvious that I was viewed in a generally good light by all subjects as I anticipated. Also, at the onset of the study, I assumed getting interracial couples would be smooth-sailing and unproblematic (see Rapley, 2006). However, a couple I thought might participate opted out because a partner did not selfidentify as a visible minority although she is evidently a minority and her spouse who is White had agreed to participate. Thus, I learned the lesson that people may not define themselves by or necessarily identify with the way they look.

As noted earlier, in talking about his experience with his Black spouse, Mark told me that they might skew my research. He assumed that my objective was simply investigating possible experiences of racism. However, questions in this study were carefully worded in order not to make subjects feel they have to respond in a certain way. Wording questions in a non-suggestive way is thus fundamental to getting subjects to bare their minds without feeling compelled that the researcher has vested interests in a particular standpoint. This is by no means a novel point, but is worth reiterating particularly for minority researchers and all involved in the field of ethnic relations in general. 


\section{Temitope Oriola}

\section{Conclusion}

This paper explored the experiences of select interracial couples in Canada through in-depth interviews. All five couples agree that interracial relationships are capable of increasing the level of integration among various ethnic groups in Canada and that Canada is largely accepting of interracial relationships even though some feel the media does not show such couples because they assume the public may not be accepting of such unions. One major finding of this study is the shift in identities and ethnic consciousness among subjects because of their relationship with spouses from different backgrounds. For most of the minority spouses, a process of renegotiation of their sense of self occurs, while their White spouses are also drawn into identifying with their spouses' backgrounds because '(i)dentity is people's source of meaning and experience' (Castells, 1997: 6).

While the interplay of identity with space, interaction, diversity, and dislocation is relatively well noted in the literature (Puplampu and Tettey, 2005; Donaldson and Jedwab, 2003; Wilkinson, 2003; Papastergiadis, 2000; Bhabha, 1994), the literature on interracial unions is yet to examine how identities, beyond awareness of racism (such as Frankenberg, 1993) are shaped and influenced by interracial relationships. Also, this study makes another significant contribution in highlighting how the worldviews of subjects are re/deconstructed by the facticity of their interracial relationships and their increasing cosmopolitan outlook.

Consequently, stories of interracial couples are not stories of atomized individuals or pairs of persons; rather, they are stories of diverse families from and of wide-ranging histories, nationalities and backgrounds. These diverse stories, as shown in this study, 
Experiences of Inter-racial Couples

move a little closer as a result of their relationships with people from different backgrounds and necessarily engender cultural learning on both sides. Minority families are found to hold greater reservations about their children marrying outside the group they come from, while the families of White subjects had more enthusiasm. The study finds that couples are generally apprehensive about their children's identities and how they will be treated in the society. Partners also vacillate between a universalistic identity discourse and particularistic identity discourse concerning their children. Subjects believe that relationships like theirs are seldom cast on television because interracial marriages are still largely believed to be very problematic and unworkable.

Some themes such as 'strong faith' and 'commonality' of interests could not be covered because of space constraints. This research is limited by the small number of couples studied and I make no generalizations about the findings, but hope that this helps in stimulating further research into interracial coupling in Canada.

\section{References}

Bannerji, H. 2000. The Dark Side of the Nation: Essays on Multiculturalism, Nationalism and Gender. Toronto: Canadian Scholars' Press.

Barn, R. and V. Harman. 2006. 'A Contested Identity: An Exploration of the Competing Social and Political Discourse concerning the Identification of Inter-Racial Parentage,' British Journal of Social Work, 36: 1309-1324.

Bhabha, H. K. 1994. The Location of Culture. Routledge: London and New York. Bissoondath, N. 2002. [orig. 1994] Selling Illusions: The Cult of Multiculturalism in Canada. Toronto: Penguin Books.

Briggs, C. L. 2007. 'Anthropology, Interviewing and Communicability in Contemporary Society,' Current Anthropology 48, 4: 551-580. 
Temitope Oriola

Brodkin, K. 2004. 'How did Jews become White Folks?' Off-White: Readings on Power, Privilege and Resistance. Pp. 17-34. New York: Routledge.

Caplan, P. 1998. Mother-Blaming, 'Bad' Mothers: The Politics of Blame in TwentiethCentury America. Pp. 127-144. New York: New York University Press.

Castells, M. 1997. The Power of Identity. The Information Age: Economy, Society and Culture. Volume iii. Malden: Blackwell.

Charon, J. 1992. Symbolic Interactionism: An Introduction, An Interpretation, An Integration. Fourth Edition. Englewood Cliffs: Prentice Hall.

Childs, E. 2005. Navigating Interracial Borders: Black-White Couples and their Social Worlds. New Brunswick: Rutgers University Press.

Coke, T. E. 2003. 'Racial Profiling Post-9/11: Old Story, New Debate,' C. Brown ed. Lost Liberties: Ashcroft and the Assault on Personal Freedom. New York: New Press.

Craig-Henderson, K. 2006. Black men in Interracial Relationships: What's Love Got to do with it? New Brunswick and London: Transaction Publishers.

DaCosta, K. 2007. Making Multiracial: State, Family and Market in the Redrawing of the Color Line. Stanford: Stanford University Press.

Davis, D.W. 1997. 'The Direction of Race of Interviewer Effects among AfricanAmericans: Donning the Black Mask,' American Journal of Political Science 4, 1: 309-322.

Deliovsky, K. 2002. 'Transgressive Whiteness: The Social Construction of White Women involved in Interracial Relationships with Black Men,' Nathani Wane, Deliovski Katerina and Erica Lawson (Eds.). Back to the Drawing Board: African-Canadian Feminisms. Toronto: Sumach Press.

Donaldson, I. and J. Jedwab. 2003. 'Intersections of Diversity,' Canadian Ethnic Studies XXXV, 3: 2-4.

Dorow, Sara. 2006. 'Racialized Choices: Chinese Adoption and the "White Noise" of Blackness,' Critical Sociology, 32, 2/3: 357-379.

Fechter, A. 2005. 'The Other stares back: Experiencing Whiteness in Jakarta,' Ethnography 6, 1: 87-103. 
Experiences of Inter-racial Couples

Frankenberg, R. 1993. White Women, Race Matters: The Social Construction of Whiteness. Minneapolis: University of Minnesota Press.

Gilgun, J. 2005. "'Grab" and Good Science: Writing Up the results of Qualitative Research' Qualitative Health Research 15, 2: 256-262.

Gilroy, P. 1990. 'One Nation Under a Groove: The Cultural Politics of "Race" and Racism in Britain,' In David T. Goldberg (Ed.). Anatomy of Racism, 263-282. Minneapolis and London: University of Minnesota Press.

Gilroy, P. 1991 There Ain't No Black in the Union Jack: The Cultural Politics of Race and Nation. Chicago: University of Chicago Press.

Gilroy, P. 2000. Against Race: Imagining Political Culture beyond the Color Line. Massachusetts: Harvard University Press.

Gilroy, P. 1993. The Black Atlantic: Modernity and Double Consciousness. Massachusetts: Harvard University Press.

Goffman, E. 1959. The Presentation of Self in Everyday Life. New York: Doubleday.

Goldberg, D. T. 2002. The Racial State. Massachusetts: Blackwell.

Gossett, T. 1997. Race: The History of an Idea in America. New York: Oxford.

Griffin, J. 2006. [orig. 1960] Black like Me. Texas: Wings Press.

Gunatatnam, Y. 2003. Researching 'Race' and Ethnicity: Methods, knowledge and Power. London: Sage.

Hall, S. (Ed.). 1997. Representation: Cultural Representation and Signifying Practices. London: Sage.

Hall, S. and P. du Gay. (Ed.). 1996. Questions of Cultural Identity. London: Sage.

Hall, S., C. Critcher, T. Jefferson, , J. Clarke and B. Roberts. 1978. Policing the Crisis: Mugging, the State and Law and Order. London: MacMillan.

Henry, F. and C. Tator. 2002. Discourses of Domination: Racial Bias in the Canadian English-Language Press. Toronto: University of Toronto Press.

Henry, F. C. Tator, Winston, M. and T. Rees. 2000. The Colour of Democracy: Racism in Canadian Society $\left(2^{\text {nd }}\right.$ edition). Toronto: Harcourt Brace Canada.

Ighodaro, M. E. 2006. Living the Experience: Migration, Exclusion and Anti-Racist Practice. Halifax: Fernwood Publishing. 
Temitope Oriola

Jacobs, J.A and T.G. Labov. 2002. 'Gender Differentials in Intermarriage among sixteen Race and Ethnic Groups', Sociological Forum, 17, 4: 621-646.

Kant, I. 2006. Toward Perpetul Peace and other Writings on Politics, Peace and History. Pauline Kleingeld (Ed.). David Colclasure (Trans.). New Haven: Yale University Press.

Kelly, J. 1998. Under the Gaze: Learning to be Black in White Society. Halifax: Fernwood Publishing.

Kim, M. and A. Chung. 2005. 'Consuming Orientalism: Images of Asian/American Women in Multicultural Advertising', Qualitative Sociology, 28, 1: 67-91.

Lazreg, M. 1988. Feminism and Difference: The Perils of Writing as a Woman on Women in Algeria. Feminist Studies, 14, 1: 81-107.

Li, P. S. 2003. Destination Canada. Toronto: Oxford University Press.

Lofland, L. 1973. A World of Strangers: Order and Action in Urban Public Space. New York: Basic Books.

Markham, A. 2005. "Go Ugly Early": Fragmented Narrative and Bricolage as Interpretive Method,' Qualitative Inquiry 11, 813-839.

Mawani, R. 2002. 'In Between and Out of Place: Mixed-Race identity, Liquor and the Law in British Colombia, 1850-1913,' Razack, Sherene (Ed.). Race, Space and the Law: Unmapping a White Settler Society. Toronto: Between the lines.

Milan, A. and B. Hamm. 2004. 'Mixed Unions,' Canadian Social Trends, Statistics Canada, Catalogue No. 11-008.

Miller, W. and B. Crabtree. 2004. 'Depth Interviewing,' Approaches to Qualitative Research: A Reader on Theory and Practice. Hesse-Bibber Sharlene Nagy and Patricia Leavy (Eds). Pp. 185- 202. New York and Oxford: Oxford University Press.

Myrdal, G. 1962. (Orig. 1944). An American Dilemma: The Negro Problem and Modern Democracy. (Volume 1) New York: Harper and Row.

Nemoto, K. (2006). Intimacy, desire, and the construction of self in relationships between Asian American women and white American men. Journal of Asian American Studies, 9, 1: 27-54. 
Experiences of Inter-racial Couples

Nemoto, K. 2008. 'Climbing the Hierarchy of Masculinity: Asian American Men's Cross-Racial Competition for Intimacy with White Women', Gender Issues, 25, 2: $80-100$.

O’Brien, S. and I. Szeman. 2004. Popular Culture: A User's Guide. Ontario: Nelson.

Oliver, M. and T. Shapiro 1997. Black Wealth, White Wealth: A New Perspective on Racial Inequality. New York: Routledge.

Padfield, M. and I. Procter. 1996. 'The Effect of Interviewer's Gender on the Interviewing Process: A Comparative Enquiry', Sociology, 30, 2: 355-366.

Palmer, J. 2006. 'Negotiating the Indistinct: Reflections of a Korean Adopted American working with Korean-Born, Korean Americans,' Qualitative Research, 6: 473495.

Papastergiadis, N. 2000. The Turbulence of Migration: Globalization, Deterritorialization and Hybridity. Malden: Polity Press.

Perry, B. and M. Sutton. 2006. 'Seeing Red over Black and White: Popular and Media Representations of Inter-racial Relationships as Precursors to Racial Violence,' Canadian Joournal of Criminology and Criminal Justice, 48, 6: 887-904.

Puplampu, K.P. and Tettey, W. J. 2005. 'Ethnicity and the Identity of African-Canadians: A Theoretical and Political Analysis,' Tettey, W.J. and Puplampu, K.P eds. 2548.The African Diaspora in Canada: Negotiating Identity and Belonging. Calgary: University of Calgary Press.

Rapoport, R. and R.N. Rappoport. 1976. 'Dual-Career Families Re-examined: New Integrations of Work and family. London: Martin Robertson.

Razack, S. 1999. 'R.D.S. v. Her Majesty The Queen,' Enakshi Dua and Angela Robertson (eds.). Scratching the Surface: Canadian Anti-Racist Feminist Thought. Toronto: Women's Press.

Rapley, T. 2006. 'Interviews,' Qualitative Research Practice. Seale, Clive, Giampietrio Gobo, Jaber F. Gubrium and David Silverman (Eds). Pp. 15-33. London: SAGE.

Romano, R. 2003. Race Mixing: Black-White Marriage in Postwar America. Massachusetts: Harvard University Press.

Romano, R. 1998. "Immoral Conduct": White Women, Racial transgressions and Custody Disputes,' Ladd-Taylor, Molly and Lauri Umansky (Eds.). "Bad" 
Temitope Oriola

Mothers: The Politics of Blame in Twentieth-century America. New York: New York University Press.

Sampson, H. and M. Thomas. 2003. 'Lone Researchers at Sea: Gender, Risk and Responsibility', Qualitative Research, 3, 2: 165-189.

Saukko, P. 2003. Doing Research in Cultural Studies: An Introduction to Classical and New Methodological Approaches. London: SAGE.

Seale, C., G. Gobo, J. Gubrium and D. Silverman. 2004. 'Introduction: Inside Qualitative Research,' Qualitative Research Practice. Seale, Clive, Giampietro Gobo, Jaber Gubrium and David Silverman (Eds.). London: SAGE.

Seljak, D. 2005. Education, Multiculturalism and Religion, Bramadat, P. nd Seljak, D. eds. Religion and Ethnicity in Canada, 178-200. Toronto: Pearson.

Statistics Canada. 2008. 'Canada's Ethnocultural Mosaic, 2006 Census.' Catalogue no. 97-562-X. Available at http://www12.statcan.ca/english/census06/analysis/ethnicorigin/pdf/97-562XIE2006001.pdf Accessed April 7, 2008.

Sacks, H. 1972. 'Notes on Police Assessment of Moral Character,' Studies in Social Interaction. D. Sudnow ed. New York: Free Press.

Seljak, D. 2005. 'Education, Multiculturalism and Religion,' Bramadat, P. and Seljak, D. (Eds.). Religion and Ethnicity in Canada, 178-200. Toronto: Pearson.

Simmel, G. 1969. 'Social Interaction as the Definition of the Group in Time and Space,' R.E. Park and E.W. Burgess eds. Introduction to the Science of Sociology. Third Edition. Chicago and London: University of Chicago Press.

Sin, C. 2007. 'Ethnic-Matching in Qualitative Research: Reversing the Gaze on 'White Others' and 'White' as 'Other,' Qualitative Research, 7: 477-499.

Tanovich, D. M. 2006. The Colour of Justice: Policing Race in Canada. Toronto: Irvin Law.

Tjora, A. 2006. 'Writing Small Discoveries: An Exploration of Fresh Observers' Observations,' Qualitative Research 6: 429-451.

Vertovec, S. and R. Cohen. 2002. 'Introduction: Conceiving Cosmopolitanism,' Vertovec, Steven and Robin Cohen. (Eds.). Conceiving Cosmopolitanism: Theory, Context and Practice. Pp. 1-22. Oxford: University Press. 
Experiences of Inter-racial Couples

Wallenstein, P. 2002. Tell the Court I Love my Wife: Race, Marriage and Law - An American History. New York: Palgrave McMillan.

Warren, C.A.B. 1988. Gender Issues in Field Research. Newbury Park, CA: Sage.

Weis, L., A. Proweller, and C. Centrie. 2004. 'Privilege and Loss inside White WorkingClass Masculinity,' Off-White: Readings on Power, Privilege and Resistance. Pp. 145-162. New York: Routledge.

Wilkinson, L. 2003. 'Advancing a Perspective on the Intersections of Diversity: Challenges for research and Social Policy,' Canadian Ethnic Studies XXXV, 3: 26-38. 